\title{
Studies on Anti-inflammatory, Antinociceptive and Antipyretic Activities of Ethanol Extract of Azadirachta indica Leaves
}

\author{
M. Mahabub-Uz-Zaman*, Nazim Uddin Ahmed, Rasheda Akter, Kabir Ahmed, \\ M. Shafiqul Islam Aziz and M. Shamsuddin Ahmed
}

Drugs and Toxin Research Division, BCSIR Laboratories, Chittagong-4220, Bangladesh.

\begin{abstract}
The present study was carried out to investigate the anti-inflammatory, antinociceptive and antipyretic activities of the crude ethanol extract of Azadirachta indica leaves on experimental animal model at three different dose level- 1g/kg, $500 \mathrm{mg} / \mathrm{kg}$ and $100 \mathrm{mg} / \mathrm{kg}$. For evaluation of the anti-inflammatory property carrageenan induced paw edema served as acute model and cotton pellet induced granuloma formation served as chronic model in rats. The acetic acid induced writhing response and hot plate test were used to assess antinociceptive activity in mice. The antipyretic activity was evaluated on yeast-induced pyrexia in rats. Acute toxicity test was also performed in rats after administration of the extract orally at high dose level $(4 \mathrm{~g} / \mathrm{kg})$. Oral administration of the ethanol extract of $A$. indica leaves significantly $(\mathrm{P}<0.05)$ suppressed the paw edema induced by carrageenan as well as granulomatous tissue formation induced by cotton pellet in rats at high dose level $(1 \mathrm{~g} / \mathrm{kg}$ ) but no significant effect was observed at $500 \mathrm{mg} / \mathrm{kg}$ and $250 \mathrm{mg} / \mathrm{kg}$ dose level. In addition, ethanol extract obtained from $A$. indica leaves $(1 \mathrm{~g} / \mathrm{kg})$ also significantly $(\mathrm{P}<0.05)$ attenuated the acetic acid induced writhing response in mice but did not show any significant protective effect on heat induced pain in mice. A significant antipyretic effect $(\mathrm{P}<0.05)$ was noticed with ethanol leaf extract of $A$. indica leaves at $1 \mathrm{~g} / \mathrm{kg}$ and $500 \mathrm{mg} / \mathrm{kg}$ dose level. In acute toxicity study, no mortality was observed at $4 \mathrm{~g} / \mathrm{kg}$ dose level. The present study also demonstrates the potential anti-inflammatory, analgesic and antipyretic effect of the ethanol extract of Azadirachta indica leaves, which supports the claims by the traditional medicine practitioners.
\end{abstract}

Keywords: Anti-inflammatory, Antinociceptive, Antipyretic, Azadirachta indica.

\section{Introduction}

Inflammation (Latin, inflammatio, to set on fire) is the complex biological response of vascular tissues to harmful stimuli, such as pathogens, damaged cells, or irritants that leads to the local accumulation of plasmatic fluid and blood cells. It is a protective attempt by the organism to remove the injurious stimuli as well as to initiate the healing process for the tissue (Underwood, 2000). However, inflammation which runs unchecked can lead to a host of diseases including different types of arthritis such as rheumatoid arthritis, shoulder tendinitis and gouty arthritis (Underwood, 2000). Inflammatory diseases are the major cause of morbidity of the working force throughout world. This has been called the 'King of Human Miseries' (Chatterjee and Pal, 1984).

Most of the drugs used presently for the management of pain and inflammatory conditions possess more or less side and toxic effects (Ahmad, et al., 1992). On the contrary many medicines of plant origin had been used since long time without any adverse effects. It is therefore essential that efforts should be taken to develop new drugs of plant origin,

\footnotetext{
*Corresponding Author, Email: mahabub582@yahoo.com
}

which will be economically feasible, as well as with lesser side effects.

Bangladesh owing to its favorable climatic influences has been blessed with immense natural resources including explored and unexplored herbal medicinal plants. We can use these resources for remedy of different diseases. Azadirachta indica (locally known as Neem) is perhaps the most useful traditional medicinal plant in Bangladesh as well as its neighboring countries. Every parts of the tree have been used as traditional medicine for household remedy against various human ailments including arthritis, gout, fever, pain, skin diseases, diabetes etc. (Ghani, 1998). The tree is regarded as 'village dispensary' in Bangladesh.

In this study, we have evaluated the anti-inflammatory, antinociceptive and antipyretic effect of ethanol extract of Azadirachta indica leaves to establish scientific evidence in support of the folklore claim. 


\section{Materials and Methods}

\section{Animals and diets}

Swiss albino mice of both sexes weighing between 30 to $35 \mathrm{~g}$ and Wistar Albino rats of the either sex weighing between 150-200 g obtained from animal house of BCSIR laboratories, Chittagong were used for the present study. The animals were acclimatized to room temperature $\left(28 \pm 5^{\mathrm{O}} \mathrm{C}\right)$ with a relative humidity of $55 \pm 5 \%$ in a standard wire meshed plastic cages for 4 to 5 days prior to commencement of the experiment. During the entire period of study the animals were supplied with standard pellet diet and water ad libitum. In this study, all the animal experimentation was carried out according to the guidelines of Institutional Animal Ethics Committee (IAEC).

\section{Collection of plant material}

The leaves of Azadirachta indicia were collected from the plantation area of BCSIR laboratories, Chittagong. The plant was taxonomically identified in the Industrial Botany Division of BCSIR laboratories, Chittagong.

\section{Preparation of ethanol extract}

The collected leaves were cut into small pieces, air dried at room temperature for about 10 days and ground into powder form and stored in an airtight container. $500 \mathrm{~g}$ powder was then macerated in $5 \mathrm{~L}$ 90\% ethanol for 7 days at room temperature with occasional stirring. The ethanol extract of the plant was collected in a separate container and concentrated under reduced pressure below $50{ }^{\circ} \mathrm{C}$ through rotatory vaccum evaporator. The concentrated extract was dried using freeze dryer (Shimadzu, Kyoto, Japan). Finally a blackishgreen colored residue was obtained (yield $5.6 \% \mathrm{w} / \mathrm{w}$ ) which was kept in a refrigerator at $4^{\mathrm{O}} \mathrm{C}$.

\section{Assay of anti-inflammatory activity}

Carrageenan induced paw edema and cotton pellet test these two models were used for evaluating potential of ethanol extract of Azadirachta indica leaves on inflammation. For each model fifteen albino rats weighting 150-160g were randomly divided into three equal groups $(n=5)$ - vehicle control [received only distilled water], positive control [received dichlophenac sodium (40 mg/kg) or indomethacin (5mg/kg)] and sample treated group [administered ethanol extract of Azadirachta indicia leaves $(1 \mathrm{~g} / \mathrm{kg}, 500 \mathrm{mg} / \mathrm{kg}$ and $100 \mathrm{mg} / \mathrm{kg})]$.

\section{Carrageenan induced paw edema}

According to the method designed by Winter et al., (1962), the initial right hind paw volume of each rat was measured using plethysmometer (UGO Basile, Italy) and then $0.1 \mathrm{ml}$ of $1 \%(\mathrm{w} / \mathrm{v})$ carrageenan was subcutaneouly injected into the sub-plantar region of the right hind paw in order to induce acute inflammation. The volume of right hind paw was measured at 1st, 2nd, 3rd and 4th hour after carrageenan injection and the paw edema was determined. Leaves extract of $A$. indicia $(1 \mathrm{~g} / \mathrm{kg}, 500 \mathrm{mg} / \mathrm{kg}$ and $100 \mathrm{mg} / \mathrm{kg})$ or standard anti-inflammatory drug dichlophenac sodium (40 mg/kg) or distilled water was administered orally one hour before the subplantar injection. The inhibitory activity was calculated according to the following formula (Olajide et al., 2000):

Percentage inhibition

$$
=\frac{(\mathrm{Ct}-\mathrm{Co}) \text { control }-(\mathrm{Ct}-\mathrm{Co}) \text { treated }}{(\mathrm{Ct}-\mathrm{Co}) \text { control }} \times 100
$$

Where Ct is the right hind paw thickness volume (in $\mathrm{mm}^{3}$ ) at time t, Co is the right hind paw thickness volume (in $\mathrm{mm}^{3}$ ) before carrageenan injection. $\mathrm{Ct}$ - Co is paw edema. (Ct-Co) control, is edema or paw size after carrageenan injection to control rats at time t. ( $\mathrm{Ct}$ - Co) treated, is edema or paw size after carrageenan injection to treated (reference or sample drug) rats at time $\mathrm{t}$.

\section{Cotton pellet test}

In this experiment chronic inflammation was induced by cotton pellet induced granuloma in albino rats - by the previously established method of Gold stein et al. (1976). Briefly, under ether anesthesia two sterilized cotton pellets weighing $10 \pm 0.5 \mathrm{mg}$ were implanted subcutaneously in the groin region of the rats, one on each side. These cotton pellets were sterilized in an air oven at $121^{\mathrm{O}} \mathrm{C}$ for 1 hour and soaked in 1 $\%$ solution of crystalline penicillin just before implantation. Leaves extract of $A$. indicia leaves $(1 \mathrm{~g} / \mathrm{kg}, 500 \mathrm{mg} / \mathrm{kg}$ and $100 \mathrm{mg} / \mathrm{kg})$, reference drug indomethacin (5 mg/kg) and controlled vehicle were administered orally according to time scheduled for seven consecutive days from 1st day of cotton pellet implantation. The animals were sacrificed on 8th day and cotton pellets were removed surgically and made free from fat and extraneous tissues. The pellets were incubated at $37{ }^{\mathrm{O}} \mathrm{C}$ for 24 hour and dried at $60{ }^{\mathrm{O}} \mathrm{C}$ to constant wt. Increment in the dried weight of the pellet was taken as the measure of granuloma formation.

\section{Assay of antinociceptive activity}

Writhing and hot plate tests were performed to evaluate the antinocipeptive activities of leaves extract of neem. 
Table I. Effect of ethanol extract of the leaves of $A$. indica on carrageenan induced paw edema

\begin{tabular}{|c|c|c|c|c|c|c|c|c|c|}
\hline \multirow[t]{2}{*}{ Group } & \multirow[t]{2}{*}{ Dose } & \multicolumn{4}{|c|}{ Paw edema $\left(\mathrm{mm}^{3}\right)$} & \multicolumn{4}{|c|}{$\begin{array}{c}\text { \% Inhibition } \\
\frac{(\mathrm{Ct}-\mathrm{C} 0) \text { control - }(\mathrm{Ct}-\mathrm{C} 0) \text { treated }}{(\mathrm{Ct}-\mathrm{C} 0) \text { control }} \times 100\end{array}$} \\
\hline & & $1 \mathrm{st} \mathrm{hr}$ & 2nd hr & 3rd hr & 4th hr & $1 \mathrm{st} \mathrm{hr}$ & 2nd hr & 3rd hr & 4th hr \\
\hline Control & - & $0.6 \pm 0.08$ & $0.79 \pm 0.09$ & $1.21 \pm 0.23$ & $1.20 \pm 0.25$ & - & - & - & - \\
\hline Diclofenac $\mathrm{Na}$ & $40 \mathrm{mg} / \mathrm{kg}$ & $0.45 \pm 0.04 *$ & $0.51 \pm 0.08 *$ & $0.65 \pm 0.08 *$ & $0.64 \pm 0.09 *$ & $25.0 \%$ & $35.4 \%$ & $46.3 \%$ & $46.7 \%$ \\
\hline A. indica ethanol extract & $1 \mathrm{~g} / \mathrm{kg}$ & $0.49 \pm 0.06$ & $0.58 \pm 0.06 *$ & $0.71 \pm 0.05^{*}$ & $0.78 \pm 0.23 *$ & $18.3 \%$ & $26.6 \%$ & $41.3 \%$ & $35.0 \%$ \\
\hline A. indica ethanol extract & $500 \mathrm{mg} / \mathrm{kg}$ & $0.50 \pm 0.09$ & $0.69 \pm 0.08$ & $0.98 \pm 0.10$ & $1.01 \pm 0.15$ & $16.7 \%$ & $12.7 \%$ & $19.0 \%$ & $15.8 \%$ \\
\hline A. indica ethanol extract & $100 \mathrm{mg} / \mathrm{kg}$ & $0.58 \pm 0.06$ & $0.72 \pm 0.05$ & $1.0 \pm 0.09$ & $1.06 \pm 0.2$ & $3.3 \%$ & $8.9 \%$ & $17.4 \%$ & $11.6 \%$ \\
\hline
\end{tabular}

All values are expressed as mean \pm SEM $(n=5)$

* $\mathrm{P}<0.05$ significant compared to control

Here,

Co is the paw thickness volume (in $\mathrm{mm}^{3}$ ) before carrageenan injection,

$\mathrm{Ct}$ is the paw thickness volume (in $\mathrm{mm}^{3}$ ) at time $\mathrm{t}$,

(Ct -Co) is paw edema

Table II. Effect of ethanol extract of the leaves of $A$. indica on cotton pellet induced granuloma formation.

\begin{tabular}{l|c|c|c}
\hline Group & Dose & $\begin{array}{c}\text { Mean increasein weight of } \\
\text { cotton pellets (mg) }\end{array}$ & $\begin{array}{c}\text { Inhibition } \\
\text { Control }\end{array}$ \\
Indomethacin & - & $20.2 \pm 0.95^{*}$ & - \\
A. indica ethanol extract & $1.8 \mathrm{mg} / \mathrm{kg}$ & $24.5 \pm 1.48^{*}$ & $34.4 \%$ \\
A. indica ethanol extract & $500 \mathrm{mg} / \mathrm{kg}$ & $28.4 \pm 1.6$ & $7.8 \%$ \\
A. indica ethanol extract & $100 \mathrm{mg} / \mathrm{kg}$ & $28.8 \pm 1.2$ & $6.5 \%$ \\
\hline
\end{tabular}

All values are expressed as mean $\pm \operatorname{SEM}(n=5)$

* $\mathrm{P}<0.05$ significant compared to control

\section{Hot plate test}

The hot plate test was conducted on mice according to the method described by Woolfe and MacDonald (1944). Male albino mice weighing 25-30 g were distributed into four groups $(n=5)$. One hour after the oral administration of leaf extract of $A$. indicia leaves $(1 \mathrm{~g} / \mathrm{kg}, 500 \mathrm{mg} / \mathrm{kg}$ and $100 \mathrm{mg} / \mathrm{kg}$ ) or standard drug dichlophenac sodium [40 $\mathrm{mg} / \mathrm{kg}$ ] or morphine (administered intraperitoneally at the rate of $5 \mathrm{mg} / \mathrm{kg}$ body weight) or normal distilled water, the mice were placed on the hot plate (Scored DS37, UGO Basile, Italy), maintained at constant temperature of $55 \pm$ $0.5^{\mathrm{O}} \mathrm{C}$ and the latency of nociceptive response such as licking and jumping were measured [the time from reaching the hot plate until it first licks a paw and try to jump out] with 30 minutes interval over 120 minutes period of time. Finally the average retention time of treated group were compared with the control group.

\section{Acetic acid induced writhing response}

For writhing test $1 \%(\mathrm{v} / \mathrm{v})$ acetic acid solution $(3.3 \mathrm{ml} / \mathrm{kg}$ body weight) was injected intraperitoneally in mice (weighing 25-30 g) and the number of writhing and stretching was counted over 20 minutes period as previously reported (Koster et al., 1959; Hendershot and Forsaith, 1959). The ethanol extract of $A$. indicia leaves $(1 \mathrm{~g} / \mathrm{kg}, 500 \mathrm{mg} / \mathrm{kg}$ and $100 \mathrm{mg} / \mathrm{kg}$ ), reference analgesic drug dichlophenac sodium (40 mg/kg) and distilled water were administered orally 30 min before acetic acid injection. 


\section{Assay of Antipyretic activity}

Antipyretic activity was carried out in Wistar albino rats weighing 130-150 g according to the method described by Adams et al. (1968). Briefly, pyrexia was induced in rats by a subcutaneous injection of $15 \%(\mathrm{w} / \mathrm{v})$ aqueous suspension of Brewer's yeast at the rate of $1 \mathrm{ml} / 100 \mathrm{~g}$ body weight. Ten hours later the rectal temperature of each rat was measured using clinical thermometer inserting to a constant depth of two centimeter. Only rats that showed an increase in temperature of at least $0.5{ }^{\mathrm{O}} \mathrm{C}$ were used for experiments. Ethanol extract of $A$. indicia leaves (1 g/ $\mathrm{kg}, 500 \mathrm{mg} / \mathrm{kg}$ and $100 \mathrm{mg} / \mathrm{kg})$ or standard antipyretic drug paracetamol (100 $\mathrm{mg} / \mathrm{kg}$ ) or vehicle control were then administered orally to different groups of rats $(n=5)$ and the temperature was measured at 1st, 2nd, and 3rd hour after drug administration.

\section{Acute toxicity studies}

Ethanol extract of $A$. indicia leaves was dosed orally at the rate of $4 \mathrm{~g} / \mathrm{kg}$ body weight on ten Wistar albino rats (weighing 150-160 gm). Five male and five female rats were closely observed for 24 hours for any mortality and next ten days for any delayed toxic effect. Their food consumption and growth rate were also examined once daily up to ten days.

\section{Statistical analysis}

All the values in the test are expressed as mean \pm SEM [Standard error of the Mean]. Statistical difference between the mean of the various groups were analyzed by using Student's "t" test. P values $<0.05$ or less were considered as significant.

\section{Results and Discussion}

Anti-inflammatory activity

The ethanol extract of the of $A$. indica leaves was evaluated for anti-inflammatory activity in acute and chronic experimental animal models and the results are depicted in Table I and II.

\section{Carrageenan induced paw edema}

As shown in Table I, the ethanol extract obtained from $A$. indica leaf ( $1 \mathrm{~g} / \mathrm{kg}$ ) exhibited anti-inflammatory activity by significant $(\mathrm{P}<0.05)$ suppression of the paw edema induced by carrageenan at 2, 3 and $4 \mathrm{~h}$ hr after carrageenan injection, though less potent than that of refer $\mathrm{mg} / \mathrm{kg}$. A. indica showed maximum inhibition of paw edema $(41.3 \%)$ at the dose of $1 \mathrm{~g} / \mathrm{kg}$ at $3 \mathrm{~h}$ after carrageenan injection. Other lower dosages of $A$. indica leaves extract $(500 \mathrm{mg} / \mathrm{kg}$ and 100 $\mathrm{mg} / \mathrm{kg}$ ) did not show any significant change in paw edema compared with vehicle control group.

\section{Cotton pellet induced granuloma}

The effects of the ethanol extract of $A$. indica $(1 \mathrm{~g} / \mathrm{kg}$, $500 \mathrm{mg} / \mathrm{kg}$ and $100 \mathrm{mg} / \mathrm{kg}$ ) and indomethacin $(5 \mathrm{mg} / \mathrm{kg})$ on the chronic model of cotton pellet induced granuloma are shown in Table II. A significant reduction $(p<0.05)$ in the weight of cotton pellets was observed with ethanol extract of A. indica $(1 \mathrm{~g} / \mathrm{kg})$ compared to the vehicle control rats though the degree of reduction (20.5\%) was comparatively lower than the effect caused by indomethacin (34.4\%). $500 \mathrm{mg} / \mathrm{kg}$ and $100 \mathrm{mg} / \mathrm{kg}$ A. indica extract also reduced the weight of cotton pellets (7.8 \% and 6.5\% respectively) but they are not found statistically significant.

Table III. Effect of ethanol extract of the leaves of $A$. indica on nociceptive response induced by heat in mice.

\begin{tabular}{l|c|c|c|c|c}
\hline \multirow{2}{*}{ Treatment } & \multirow{2}{*}{ Dose } & \multicolumn{4}{|c}{ Reaction time (sec) } \\
\cline { 3 - 5 } & & $30 \mathrm{~min}$ & $60 \mathrm{~min}$ & $90 \mathrm{~min}$ & $120 \mathrm{~min}$ \\
\hline Control & - & $10.2 \pm 1.4$ & $8.5 \pm 1.0$ & $5.0 \pm 0.8$ & $5.0 \pm 1.1$ \\
Diclofenac Sodium & $40 \mathrm{mg} / \mathrm{kg}$ & $9.5 \pm 1.1$ & $10.5 \pm 0.8$ & $9.5 \pm 0.6$ & $4.5 \pm 0.5$ \\
Morphine & $5 \mathrm{mg} / \mathrm{kg}$ & $58.2 \pm 1.2 * *$ & $45.0 \pm 0.6 * *$ & $33.5 \pm 1.0 * *$ & $35.4 \pm 0.7 * *$ \\
A. indica ethanol extract & $1 \mathrm{~g} / \mathrm{kg}$ & $7.5 \pm 0.6$ & $6.0 \pm 1.2$ & $7.5 \pm 1.4$ & $10.0 \pm 2.8$ \\
A. indica ethanol extract & $500 \mathrm{mg} / \mathrm{kg}$ & $7.0 \pm 0.8$ & $6.2 \pm 1.5$ & $5.2 \pm 1.2$ & $7.2 \pm 1.2$ \\
A. indica ethanol extract & $100 \mathrm{mg} / \mathrm{kg}$ & $5.0 \pm 1.3$ & $4.5 \pm 1.6$ & $6.0 \pm 0.9$ & $4.0 \pm 1.2$ \\
\hline
\end{tabular}

All values are expressed as mean $\pm \operatorname{SEM}(n=5)$

** $\mathrm{P}<0.001$ significant compared to control. 


\section{Antinociceptive Activities}

\section{Hot plate test}

The ethanol extract of $A$. indica $(1 \mathrm{~g} / \mathrm{kg}, 500 \mathrm{mg} / \mathrm{kg}$ and 100 $\mathrm{mg} / \mathrm{kg}$ ) and diclofenac sodium ( $40 \mathrm{mg} / \mathrm{kg}$ ) did not show any significant protective effect on heat induced pain in mice. In contrast, a centrally acting analgesic drug, morphine $(5 \mathrm{mg} / \mathrm{kg})$ markedly increased $(\mathrm{P}<0.01)$ pain latency (Table III).

\section{Acetic acid induced writhing response}

Table IV shows the pain behavior of writhing response, which was presented as cumulative abdominal stretching response. The treatment of animals with ethanol extract of $A$. indica $(1 \mathrm{~g} / \mathrm{kg})$ produced a significant $(\mathrm{P}<0.05)$ inhibition in abdominal writhes produced by acetic acid. However the degree of inhibition was less than the effect caused by standard analgesic drug diclofenac sodium (40 mg/kg). Other lower dosages of $A$. indica leaves extract $(500 \mathrm{mg} / \mathrm{kg}$ and 100 $\mathrm{mg} / \mathrm{kg}$ ) did not show any significant effect on writhing response of mice compared with control.

Table IV. Effect the of $A$. indica ethanol extract on 1\% $(v / v)$ acetic acid induced writhing response

\begin{tabular}{l|c|c}
\hline Treatment & Dose & $\begin{array}{c}\text { No. of Writhing } \\
\text { (Counts/20 min) }\end{array}$ \\
\hline Control & - & $72.75 \pm 2.2$ \\
Paracetamol & $100 \mathrm{mg} / \mathrm{kg}$ & $18.50 \pm 5.5^{* *}$ \\
A. indica ethanol extract & $1 \mathrm{~g} / \mathrm{kg}$ & $55.92 \pm 4.5^{*}$ \\
A. indica ethanol extract & $500 \mathrm{mg} / \mathrm{kg}$ & $68.26 \pm 3.2$ \\
A. indica ethanol extract & $100 \mathrm{mg} / \mathrm{kg}$ & $70.2 \pm 4.8$ \\
\hline
\end{tabular}

All values are expressed as mean \pm SEM $(n=5)$

* $\mathrm{P}<0.05$ and ** $\mathrm{P}<0.01$ significant compared to control

\section{Antipyretic activities}

Table $\mathrm{V}$ shows the effects of the ethanol extract of $A$. indica and reference drug paracetamol on yeast induced pyrexic rats. A. indica extract showed antipyretic activity in a dose dependent manner but found significant $(\mathrm{P}<0.05)$ at $1 \mathrm{~g} / \mathrm{kg}$ and $500 \mathrm{mg} / \mathrm{kg}$ dose level which is almost comparable to standard antipyretic drug paracetamol

\section{Acute toxicity test}

In the acute toxicity assay of ethanol extract of $A$. indica leaves, no deaths were observed at high $(4 \mathrm{~g} / \mathrm{kg})$ dose level. At this dose level, animals also did not show any stereotypical symptoms associated with toxicity, such as convulsion, ataxy, diarrhoea or increased diuresis. Behavior of all treated animals appeared normal and no significant change in the body weight as well as their daily food consumption were observed. Hence, the extract was considered to be without gross or acute toxic effects on rats.

The results of the present study revealed that the ethanol extract of $A$. indica leaves possess significant $(\mathrm{P}<0.05)$ antiinflammatory, antiniceptive and antipyretic activity. The acute toxicity studies showed that the extract has a high safety profile as neither death nor symptoms associated with toxicity was observed at high dose level $(4 \mathrm{~g} / \mathrm{kg})$ in rats. Our results are consistent with other previous findings (Khanna et al., 1995; Pillai, et al., 1978, Pillai and Santhakumari, 1981).

Carrageenan induced paw edema is a suitable test for evaluating anti-inflammatory properties for natural drugs because of its sensitivity in detecting orally active anti-inflammatory agents particularly in the acute phase of inflammation (DiRosa et al., 1971). Development of edema in the paw of rat after injection of carrageenen is a biphasic event (Vinger et al., 1969). The initial phase observed during the first hour is attributed to the release of histamine and serotonin. The second phase of edema is due to the release of prostaglandins, protease, and lysosome (Crunkhon and Meacock, 1971). The results of the present study demonstrate that the ethanol extract $(1 \mathrm{~g} / \mathrm{kg})$ obtained from $A$. indi$c a$ leaf exhibited significant anti-inflammatory activity at 2 , 3 and $4 \mathrm{hr}$ after carrageenan injection. Therefore it is possible that the ethanol extract of $A$. indica contains the active constituents that exhibits its anti-infl-ammatory action probably by means of either inhibiting the synthesis, release or action of inflammatory mediators e.g. histamine, serotonin and prostaglandins.

The cotton pellet induced granuloma formation, is a model of chronic inflammation (Ismail et al. 1997) and the dry weight of pellet has been shown to correlate with the amount of granulomatous tissue formed (Swingle and Shideman, 1972). Chronic inflammation is a reaction arising when the acute response is insufficient to eliminate proinflammatory agents. Chronic inflammation includes a proliferation of fibroblasts and the infiltration of neutrophils and exudation (Dunne, 1990; Arrigoni-Maratellie, 1988). Chronic inflammation occurs by means of the development of proliferative cells. These cells can be either spread or in granuloma form. The ethanol extract of Azadirachta indica leaf $(1 \mathrm{~g} / \mathrm{kg})$ showed significant $(\mathrm{P}<0.05)$ anti-inflammatory activity in cotton-pellet induced granuloma and thus found to be effective in chronic inflammatory conditions, which reflected its efficacy in inhibiting the increase in the number of fibrob 
Table V. Effect of ethanol leaves extract of $A$. indica on yeast-induced pyrexia in rats.

\begin{tabular}{|c|c|c|c|c|c|c|}
\hline \multirow[t]{2}{*}{ Treatment } & \multirow[t]{2}{*}{ Dose } & \multicolumn{2}{|c|}{ Rectal temperature $\left({ }^{\circ} \mathrm{C}\right)$} & \multicolumn{3}{|c|}{ Rectal temperature after administration of drug $\left({ }^{\circ} \mathrm{C}\right)$} \\
\hline & & $\begin{array}{l}\text { Initial } \\
\text { (A) }\end{array}$ & $\begin{array}{l}\text { 10th hour after } \\
\text { yeast } \\
\text { administration } \\
\text { (B) }\end{array}$ & $\begin{array}{c}\text { 1st hr } \\
\left(\mathrm{C}_{1}\right)\end{array}$ & $\begin{array}{c}\text { 2nd hr } \\
\left(\mathrm{C}_{2}\right)\end{array}$ & $\begin{array}{c}\text { 3rd hr } \\
\left(\mathrm{C}_{3}\right)\end{array}$ \\
\hline Control & - & $37.61 \pm 0.17$ & $38.30 \pm 0.16$ & $\begin{array}{c}38.29 \pm 0.12 \\
(1.4 \%)\end{array}$ & $\begin{array}{c}38.28 \pm 0.15 \\
(1.61 \%)\end{array}$ & $\begin{array}{c}38.27 \pm 0.08 \\
(3.63 \%)\end{array}$ \\
\hline Paracetamol & $100 \mathrm{mg} / \mathrm{kg}$ & $37.44 \pm 0.14$ & $38.10 \pm 0.15$ & $\begin{array}{c}37.70 \pm 0.17^{* *} \\
(61 \%)\end{array}$ & $\begin{array}{c}37.62 \pm 0.14^{* *} \\
(73.2 \%)\end{array}$ & $\begin{array}{c}37.50 \pm 0.12^{* *} \\
(91.5 \%)\end{array}$ \\
\hline $\begin{array}{l}\text { A. indica ethanol } \\
\text { extract }\end{array}$ & $1 \mathrm{~g} / \mathrm{kg}$ & $37.7 \pm 0.2$ & $38.22 \pm 0.18$ & $\begin{array}{c}38.0 \pm 0.2^{*} \\
(41.7 \%)\end{array}$ & $\begin{array}{c}37.9 \pm 0.18^{*} \\
(60.4 \%)\end{array}$ & $\begin{array}{c}37.85 \pm 0.17^{* *} \\
(69.8 \%)\end{array}$ \\
\hline $\begin{array}{l}\text { A. indica ethanol } \\
\text { extract }\end{array}$ & $500 \mathrm{mg} / \mathrm{kg}$ & $37.69 \pm 0.2$ & $38.44 \pm 0.18$ & $\begin{array}{c}38.2 \pm 0.18 \\
(30.3 \%)\end{array}$ & $\begin{array}{c}38.12 \pm 0.18^{*} \\
\quad(40.3 \%)\end{array}$ & $\begin{array}{c}38.00 \pm 0.18^{*} \\
(55.1 \%)\end{array}$ \\
\hline $\begin{array}{l}\text { A. indica ethanol } \\
\text { extract }\end{array}$ & $100 \mathrm{mg} / \mathrm{kg}$ & $37.50 \pm 0.2$ & $38.2 \pm 0.18$ & $\begin{array}{c}38.3 \pm 0.18 \\
(10.0 \%)\end{array}$ & $\begin{array}{c}38.10 \pm 0.18 \\
(22.8 \%)\end{array}$ & $\begin{array}{c}38.05 \pm 0.18 \\
(29.3 \%)\end{array}$ \\
\hline
\end{tabular}

All values are expressed as mean $\pm \operatorname{SEM}(n=5)$

$* \mathrm{P}<0.05$ and ** $\mathrm{P}<0.01$ significant compared to control

Percentage reduction in rectal temperature is given within parentheses

$\%$ Reduction $=\frac{B-C_{n}}{B-A} \times 100$; where $n=1,2,3$

lasts and synthesis of collagen and mucopolysaccharides during granuloma tissue formation (Recio et al., 1995).

The analgesic model used in the present study was chosen in order to test different nociceptive stimuli, namely cutaneous thermic (hot plate) and chemical visceral (writhing) stimuli. In acetic acid induced abdominal writhing, which is the viceral pain model, the processor, the release of arachidonic acid via cyclooxygenase and prostaglandin via synthesis plays a role in the neoceptive mechanism. Results of the present study show that the ethanol extract obtained from $A$. indica leaf $(1 \mathrm{~g} / \mathrm{kg})$ produces significant $(\mathrm{P}<0.05)$ antinociceptive effect and this effect may be due to inhibition of the synthesis of the arachidonic acid metabolite (Vane, 1987).

Thermal painful stimuli are known to be selective to centrally, but not peripherally, acting analgesic drugs (Chau, 1989). In the present study, morphine (5 mg/kg), a centrally acting analgesic drug, produced a significant $(\mathrm{P}<0.001)$ inhibitory effect on the nociceptive response in this test while ethanol extract of $A$. indica and peripherally acting analgesic drug, diclofenac sodium a failed to affect the response. This result indicates that probably A. indica doesn't contain any active constituents to act against pain, which is originated from CNS.
The ethanol extract of the leaves of $A$. indicia also showed appreciable antipyretic effect (up to $70 \%$ ) on rats. This effect might be due to inhibition of the synthesis of prostaglandin $E_{2}$ which is described as key mediator of fever (Dascombe, 1985).

The presence of flavonoids, tannins, alkaloids and tetranortriterpenes, including nimbin, nimbinin, nimbidinin, nimbolide and nimbidic acid in the leaves extract of this plant (Basks, 1968) may be responsible for the anti-inflammatory, analgesic and antipyretic property demonstrated by A. indi$c a$, as these phytochemicals are well-known for their ability to inhibit inflammation, pain and fever (Biswas et al., 2002; Ferrandiz and Alcaraz, 1991; Brasseur, 1989). Moreover, recent research findings revealed that nimbidin significantly suppresses some of the functions of macrophases and neutrophils and also inhibited nitric oxide (NO) and prostaglandin $\mathrm{E}_{2}\left(\mathrm{PGE}_{2}\right)$ production relevant to the inflammatory response (Kaur et al., 2004). So, it is not unreasonable to speculate that nimbidin and related compounds like nimbidinin, nimbolide of $A$. indica leaf extract are probably responsible for its anti-inflammatory, analgesic and antipyretic effects. 


\section{Conclusion}

The ethanol extract of the leaves of $A$. indica shows a significant anti-inflammatory (both acute and chronic), peripheral analgesic and antipyretic effects in experimental animal models and could be an alternative source to treat inflammation, arthritis, pain and fever. However, further studies are necessary to elucidate the mechanism behind this effect. This report may serve as a footstep on this aspect.

\section{Acknowledgement}

The authors are grateful to Dr. Md. Yousof, C.S.O. BCSIR laboratories, Chittagong for his useful advice and identification of plant for the study. We also extend our thanks to Md. Rafique Uddin Chowdhury, Mohammad Mostafa, Abdul Auwal Khandakar, technician of Drugs and Toxins division for preparation of extracts and maintenance of animals.

\section{References}

Adams S. S., Hebborn P., and. Nicholson J. S. (1968) Some aspects of the pharmacology of ibufenac, a nonsteroidal anti-inflammatory agent. J. Pharm. Pharmac. 20: 305-312.

Ahmad F., Khan R. A., and Rasheed S. (1992) Study of analgesic and anti-inflammatory activity from plant extracts of Lactuca scariola and Artemisia absinthium. J. Islam. Aca. Sci. 5: 111-114.

Arrigoni-Maratellie E. (1988) Inflammation Antiinflammatory. (Spectrum Publication Inc, New York) pp 119120.

Basak S. P., and Chakraborty D. P. (1968) Chemical investigation of Azadirachta indica leaf (Melia azadirachta). J. Indi. Chemi. Soc. 45: 466 - 467.

Brasseur T. (1989) Antiinflammatory properties of flavonoids. J. Pharm. Belg. 44: 235-41.

Biswas K., Chattopadhyay K., Banerjee R. K, and Bandyopadhyay, U. (2002) Biological activities and medicinal properties of neem (Azadirachta indica). Curr. Scien. 82:1336-1345.

Chatterjee G. K., and Pal S. P. (1984) Search for anti-inflammatory agents from Indian Medicinal Plants. Indi. Drug. 21: 413.

Crunkhon P., and Meacock S. E. R. (1971) Mediators of inflammation induced in the rat paw by carrageenan. Brit. J. Pharmacol. 42: 392-402.
Chau T. (1989) Pharmacology methods in the control of inflammation. Moder. Meth. Pharmacol. 5: 195-212.

Dascombe M. J. (1985) The pharmacology of fever. Prog. Neurobiol. 25: 327-373.

DiRosa M., Giroud J. P., and Willoughby D. A. (1971) Studies of the acute inflammatory response induced in rats in different sites by carrageenan and turpentine. $J$. Pathol. 104:15-29.

Dunne M. W. (1990) Pathophysiology: Concepts of altered Health States with Contributors. In: Porth, C.M., Lippincott (eds.), Philadelphia. pp 165-176.

Ferrandiz M., and Alcaraz M. J. (1991) Anti-inflammatory activity and inhibition of arachidonic acid metabolites by flavonoids. Agen. Action. 32: 283-288.

Ghani A. (1998) Medicinal Plants of Bangladesh: Chemical Constituents and Uses. (Asiatic Society of Bangladesh, Dhaka) pp 93-94.

Goldstein S., Shemano I., Demes R., and Beilier J. M. (1976) Cotton pellet granuloma method for evaluation of antiinflammatory activity. Arch. Intern. Pharmacodyn. Therap. 165: 294-301

Hendershot L. C., and Forsaith J. (1959) Antagonism of the frequency of phenylquinone-induced writhing in the mouse by weak analgesics and nonanalgesics. $J$. Pharmacol. Exp. Ther. 125: 237-240.

Ismail T. S., Gapalakrisan S., Begum V. H., and Elango V. (1997) Anti-inflammatory activities of Salacia oblonga wall and Azima tetracantha Lam. J. Ethnopharmacol. 56: 145-152.

Koster R., Anderson M., and De Beer E. J. (1959) Acetic acid for analgesic screening. Fed. Proc. 18: 412.

Kaur G., Sarwar-Alam M., and Athar M. (2004) Nimbidin suppresses functions of macrophages and neutrophils: relevance to its antiinflammatory mechanisms. Phytother. Res. 18: 419-24

Khanna N., Goswami M., Sen P., and Ray A. (1995) Antinociceptive action of Azadirachta indica (neem) in mice: possible mechanisms involved. Indian. J. Exp. Biol. 33: 848-50.

Olajide O. A., Awe S. O., Makinde J. O., Ekhelar A. I., Olusola A., Morebise O., and Okpako D. T. (2000) Studies on the anti-inflammatory, antipyretic and analgesic properties of Alstonia boonei stem bark. J. 
Ethnopharmacol. 71:179-186.

Pillai N. R., Suganthan D., Seshadri C., and Santhakumari G. (1978) Analgesic and anti-pyretic actions of nimbidin. Bull. Med. Ethno. Bot. Res. 1: 393-400.

Pillai N. R., and Santhakumari G. (1981) Anti-arthritic and anti-inflammatory actions of nimbidin. Planta. Medica. 43: 59-63.

Recio M. C., Giner R. M., Manez S., and Ros J. L. (1995) Structural requirements for the anti-inflammatory activity of natural triterpenoids. Planta. Med. 6: 182185.

Swingle K. F., and Shideman F. E. (1972) Phases of Inflammatory response to subcutaneous implantation of Cotton pellet and other modifications by certain anti-inflammatory agents. J. pharmacol. Exp. Ther. 183: 226-234.
Underwood J. C. E. (2000) General systematic pathology. 3rd ed. (Churchill Livingstone, New York) pp 201.

Vinegar R., Schreiber W., and Hugo R. (1969) Biphasic development of carrageenan edema in rats. J. pharmacol. Exp. Ther. 166: 96-103.

Vane J. (1987) The evolution of non-steroidal anti-inflammatory drugs and their mechanisms of action. Drug. 1: 18-27.

Winter C. A., Risley E. A., and Nuss G. W. (1962) Carrageenin-induced edema in hind paws of the rat as an assay for antiinflammatory drugs. Proc. Soc. Exp. Biol. Med. 111: 544-547.

Woolfe G., and MacDonald A. D. (1944) The evaluation of the analgesic action of pethidine hydrochloride (Demerol). J. Pharmacol. Exp. Ther. 80: 300-307.

Received : March, 30, 2008;

Accepted : October 15, 2008. 